\title{
An Interesting Case of Green Urine
}

\author{
Muzamil Latief ${ }^{1}$, Farhat Abbas ${ }^{2}$, Summyia Farooq ${ }^{3}$
}

\begin{abstract}
Introduction: Methylene blue is a commonly available stain used to see through microscope. Methylene blue is added to bacteria on a glass slide and examined under the microscope. It has been used in the laboratory and clinical science as well as in deciphering any leakage and breach of mucosal barrier as a treatment modality in cyanide poisoning.

Case description:We report a 36-year-old male patient, a shopkeeper by occupation, who accidently had ingested methylene blue and noticed change in his urine color to green. The patient was evaluated and found to be hemodynamically stable with the normal renal, liver, and complete blood picture. The patient was observed for the next 2 days and the green urine color disappeared.

Conclusion: Though different urine colors are a clue to underlying pathologic and physiologic state, many a times, it can be a truly benign picture. Methylene blue is one such example.

Keywords: Dye, Green urine, Methylene blue.

Journal of Postgraduate Medicine Education and Research (2019): 10.5005/jp-journals-10028-1329
\end{abstract}

\section{INTRODUCTION}

Urine is an important byproduct of metabolic processes in the body, and therefore, its physical and chemical characteristics depict in some ways the physiologic and pathologic state of a body. Depending on the urine characteristics including color, various differential diagnosis are thought about and are accordingly investigated. We report a benign condition leading to green color of urine in a patient. It is a condition that has been rarely reported in literature.

\section{Case Description}

Our patient was a 36-year-old male, shopkeeper by occupation, who had accidently ingested a dye (methylene blue), a day prior to reporting at our hospital. He noticed greenish color of his urine and reported to us. There were no history of fever, dysuria, surgical intervention, trauma, and abdomen pain. The patient was hemodynamicaly stable with unremarkable systemic examination and had an urine output of 1.6 liters over 24 hours. His renal functions, liver functions, and complete blood picture were normal, and ultrasound sonography test (USG) abdomen was normal. Urine was green in color otherwise urine examination was also unremarkable (Fig. 1).

The patient was observed over the next 2 days and greenish color of urine had disappeared. So it was thought that the color change of urine was because of the dye and hence no further workup was done, and the patient was reassured about the benign nature of this condition.

\section{Discussion}

Methylene blue dye is a commonly used dye in Scientific Laboratories. It is a synthetic basic dye and stains negatively charged cell components like nucleic acids. ${ }^{2}$ It has an use both in the laboratory sciences and clinical medicine. It finds its use in conditions like cyanide poisoning leading to methemoglobinemia; this agent converts methemoglobin to hemoglobin. It is used in ruling out mucosal breaches and fistula and also in localizing the sentinel nodes of a tumor during surgery. It is a benign compound

\begin{abstract}
${ }^{1}$ Nephrology Division, Gandhi Medical College and Hospital, Secunderabad, Telangana, India

${ }^{2}$ Department of Pathology, Sher-i-Kashmir Institute of Medical Sciences, Srinagar, Jammu and Kashmir, India

${ }^{3}$ Department of Pathology, Government Medical College, Srinagar,
\end{abstract} Jammu and Kashmir, India

Corresponding Author: Muzamil Latief, Nephrology Division, Gandhi Medical College and Hospital, Secunderabad, Telangana, India, Phone: +91 7780835208, e-mail: muzamillatief.b@gmail.com

How to cite this article: Latief M, Abbas F, et al. An Interesting Case of Green Urine. J Postgrad Med Edu Res 2019;53(3):128-129.

Source of support: Nil

Conflict of interest: None

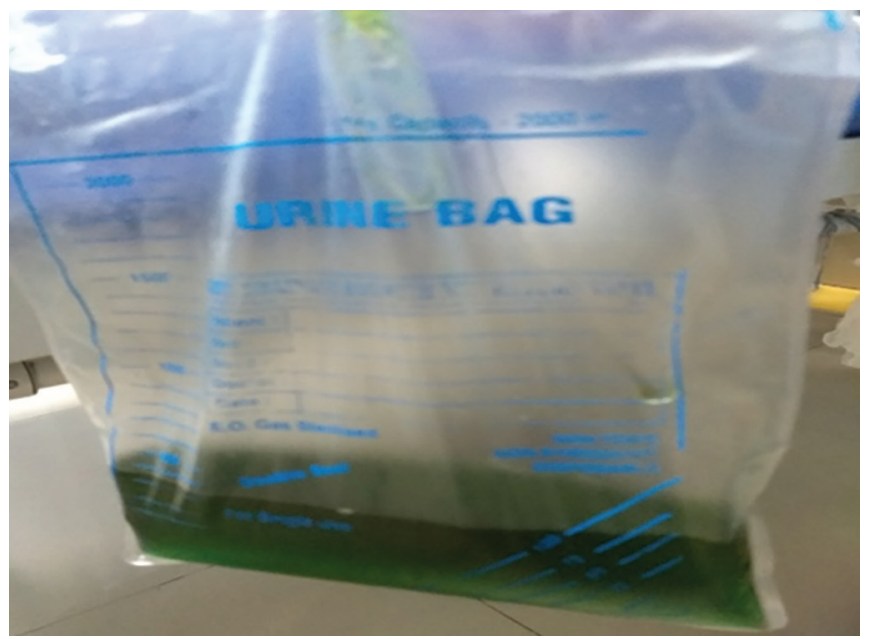

Fig. 1: Green urine

and is excreted by kidneys without causing any harm to the human body. Greenish color of urine can be caused by various substances and drugs such as cimetidine, amitriptyline, flupirtine indomethacin, and anetsthetic agents like propofol. ${ }^{3}$ Apart from

() The Author(s). 2019 Open Access This article is distributed under the terms of the Creative Commons Attribution 4.0 International License (https://creativecommons. org/licenses/by-nc/4.0/), which permits unrestricted use, distribution, and non-commercial reproduction in any medium, provided you give appropriate credit to the original author(s) and the source, provide a link to the Creative Commons license, and indicate if changes were made. The Creative Commons Public Domain Dedication waiver (http://creativecommons.org/publicdomain/zero/1.0/) applies to the data made available in this article, unless otherwise stated. 
drugs conditions such as Hartnup disease, vesicoenteral fistula leading to biliary leak into the urine, and pseudomonal urinary tract infection can also result in green colored urine. Another case report of green colored urine has been reported due to a breath freshner Cloret (Actizol). ${ }^{4}$ Methylene blue is also a rare cause of green urine, and few case reports have been published., ${ }^{1,5}$

\section{CONCLUSION}

Though different urine colors are a clue to underlying pathologic and physiologic state, many a times, it can be a truly benign picture. Methylene blue is one such example.

\section{References}

1. Stratta P, Barbe MC. Images in clinicalmedicine. Green urine. N Engl J Med 2008;358:e12. DOI: 10.1056/NEJMicm065416.

2. Methylene BlueAnhydrous, https://pubchem.ncbi.nIm.nih.gov/ compound/methylene_blue\#section=Top.

3. Leclercq P, Loly C, et al. Green urine. Lancet 2009;373:1462. DOI: 10.1016/S0140-6736(09)60309-3.

4. Elkoundi $A$, Bensghir $M$, et al. Green urine in the operating room: the "Cloret Sign". OJM 2018;111(4):265-266. DOI: 10.1093/qjmed/ hcx219.

5. Koratala A, Leghrouz M. Green urine. Clin Case Rep 2017;5(4):549-550. DOI: 10.1002/ccr3.891. 